\title{
Evaluation of Clinical Features and Renal Replacement Therapy in Children with Typical Hemolytic Uremic Syndrome
}

\author{
Tipik Hemolitik Üremik Sendromlu Çocuklarda Klinik Özelliklerin ve \\ Renal Replasman Tedavisinin Değerlendirilmesi
}

\author{
Tulin GUNGOR ${ }^{1}$, Deniz KARAKAYA ${ }^{1}$, Evrim KARGIN CAKICl ${ }^{1}$, Fatma YAZILITAS ${ }^{1}$, Mutlu UYSAL YAZICl ${ }^{2}$, \\ Evra CELIKKAYA ${ }^{1}$, Ebru AZAPAGASI ${ }^{2}$, Mehmet BULBUL ${ }^{1}$
}

1Department of Pediatric Nephrology, Dr. Sami Ulus Maternity and Child Health and Diseases Training and Research Hospital, Ankara, Turkey

2Department of Pediatric Intensive Care, Dr. Sami Ulus Maternity and Child Health and Diseases Training and Research Hospital, Ankara, Turkey

\begin{abstract}
Objective: A subset of typical Hemolytic-uremic syndrome (HUS) patients requires initiation of renal replacement therapy (RRT) despite aggressive medical intervention. This study aims to evaluate the clinical and laboratory findings of patients diagnosed with typical HUS and efficacy and safety of peritoneal dialysis (PD) and hemodialysis (HD) were compared in managing these cases.
\end{abstract}

Material and Methods: Patients having a diagnosis of typical HUS were retrospectively determined, and assessment the effects of RRT modalities on renal survival.

Results: The present study included 49 children with typical HUS, and the mean age was $2.99 \pm 1.88$ years. Neurological involvement was detected in 15 (30.6\%) patients. The neutrophil/lymphocyte ratio (NLR) was significantly higher in the neurological involvement group [odds ratio $(\mathrm{OR}) 15.42,95 \% \mathrm{Cl}(3.39-70.1), \mathrm{p}=0.005$ ]. In total, 43 (87.7\%) patients received RRT and the median time from the first recorded symptom to RRT was six days (range 3-11). While throughout RRT, 10.2\% of patients required mechanical ventilation. In this study, 26 (53.1\%) patients were managed with PD, and 17 (34.6\%) patients were managed with HD. During follow-up, 10.2\% of all patients progressed to chronic kidney disease (CKD), proteinuria was detected in $6.1 \%$ and hypertension in $4.08 \%$. The risk of CKD was significantly lower in the 3-month period in PD patients than in HD patients (odds ratio $(\mathrm{OR}) 7.69,95 \% \mathrm{Cl}(0.77-76.07), \mathrm{p}=0.04$ ).

Conclusion: We concluded that PD might be as effective and safer as HD concerning kidney recovery. Clinical features and inflammatory markers can predict neurological involvement in typical HUS cases.

Key Words: Children, Biomarkers, Renal replacement therapy, Typical Hemolytic uremic syndrome

öz

Amaç: Tipik hemolitik üremik sendrom (HÜS) hastalarının bazılarında, agresif tıbbi müdahaleye rağmen renal replasman tedavisi (RRT) gerekebilir. Bu çalısmanın amacı, tipik HÜS tanısı alan hastaların klinik ve laboratuvar bulgularının değerlendirilmesi, HÜS tanılı hastalarda periton diyalizi (PD) ile hemodiyalizin (HD) etkinlik ve güvenilirliğinin karşılaştıılmasıdır.

(i)

0000-0002-5881-1565: GUNGOR T 0000-0001-7720-4923: KARAKAYA D 0000-0001-6483-8978: KARGIN CAKICI E 0000-0001-6483-8978: YAZILITAȘ F 0000-0001-7377-4718: UYSAL YAZICI M 0000-0001-7377-4718: UYSAL YAZICI M 0000-0002-0684-8219: AZAPAGASI E 0000-0001-9007-9653: BULBUL M
Conflict of Interest / Çıkar Çatışması: On behalf of all authors, the corresponding author states that there is no conflict of interest.

Ethics Committee Approval / Etik Kurul Onayr: This study was conducted in accordance with the Helsinki Declaration Principles. Study Sami Ulus Obstetrics, Gynecology and Child Health and Diseases Clinical Research Ethics Committee approved (Number: E-21/03-119-04.03.2021).

Contribution of the Authors / Yazarların katkısI: GUNGOR T: Constructing the hypothesis or idea of research and/or article, Planning methodology to reach the Conclusions, Organizing, supervising the course of progress and taking the responsibility of the research/study, Taking responsibility in patient follow-up, collection of relevant biological materials, data management and reporting, execution of the experiments, Taking responsibility in logical interpretation and conclusion of the results, Taking responsibility in necessary literature review for the study, Taking responsibility in the writing of the whole or important parts of the study, Reviewing the article before submission scientifically besides spelling and grammar. KARAKAYA D: Constructing the hypothesis or idea of research and/or article. KARGIN CAKICI E: Planning methodology to reach the Conclusions, Taking responsibility in the writing of the whole or important parts of the study. YAZILITAŞ F: Organizing, CAKICIE: Planning methodology to reach the Conclusions, Taking responsibility in the writing of the whole or important parts of the study. YAZILITAŞ F: Organizing,
supervising the course of progress and taking the responsibility of the research/study, Taking responsibility in the writing of the whole or important parts of the study.
UYSAL YAZICI M: Organizing, supervising the course of progress and taking the responsibility of the research/study, Taking responsibility in necessary literature review for the study. CELIKKAYA E: Taking responsibility in patient follow-up, collection of relevant biological materials, data management and reporting, execution of the experiments. AZAPAGASI E: Taking responsibility in necessary literature review for the study. BULBUL $\boldsymbol{M}$ : Constructing the hypothesis or idea of research and/or article, Taking responsibility in logical interpretation and conclusion of the results, Reviewing the article before submission scientifically besides spelling and grammar.

How to cite / Atıf yazım şekli : Gungor T, Karakaya D, Kargin Cakici E, Yazilitas F, Uysal Yazici M, Celikkaya E, et al. Evaluation of Clinical Features and Renal Replacement Therapy in Children with Typical Hemolytic Uremic Syndrome. Turkish J Pediatr Dis 2022;16:127-133.
Correspondence Address / Yazıșma Adresi:

\section{Tulin GUNGOR}

Department of Pediatric Nephrology,

Dr. Sami Ulus Maternity and Child Health and Diseases Training

and Research Hospital, Ankara, Turkey

E-posta: tulingungor84@gmail.com
Received / Geliş tarihi : :02.11.2021 Accepted / Kabul tarihi : 08.12.2021

Online published 10.02 .2022

Elektronik yayın tarihi

DOI: 10.12956/tchd.1018164 
Gereç ve Yöntemler: Tipik HÜS tanısı olan hastalar retrospektif olarak belirlendi ve RRT modalitelerinin renal sağ kalım üzerindeki etkisi değerlendirildi.

Bulgular: Çalışmaya tipik HÜS tanılı 49 hasta dahil edildi ve ortalama yaşları $2.99 \pm 1.88$ yıldı. Nörolojik tutulum 15 (\%30.6) hastada saptandı. Nötrofil/lenfosit oranı nörolojik tutulum olan grupta anlamlı olarak yüksek bulundu [olasılık oranı (OO) 15.42 , \%95 güven aralığı (GA) (3.39-70.1), $p=0.005]$. Toplamda 43 (\%87.7) hastaya RRT uygulandı ve ilk kaydedilen semptomdan RRT'ye kadar geçen ortanca süre 6 gündü (aralık 3-11). RRT boyunca hastaların \%10.2'sinde mekanik ventilasyon desteği gerekti. Yirmi altı (\%53.1) hastada PD, 17 (\%34.6) hastada HD yapılmıştı. Takipte tüm hastaların \%10.2'si kronik böbrek hastalığına (KBH) ilerledi, \%6.1'inde proteinüri ve \%4.08'inde hipertansiyon saptandı. PD yapılan hastalarda 3 aylık dönemde KBH riski HD yapılan hastalara göre anlamlı olarak daha düşüktü [ OO 7.69, \%95 GA (0.77-76.07), $p=0.04]$.

Sonuç: Böbrek iyileşmesi açısından PD'in HD kadar etkili hatta daha güvenli olabileceği sonucuna vardık. Tipik HüS vakalarında klinik Özellikler ve inflamatuar belirteçler sayesinde nörolojik tutulum tahmin edilebilir.

Anahtar Sözcükler: Çocuklar, Biyomarkerlar, Renal replasman tedavisi, Tipik Hemolitik üremik sendrom

\section{INTRODUCTION}

Hemolytic uremic syndrome (HUS) is one of the most common etiologies for acute kidney injury (AKI) and a critical cause of acquired chronic kidney disease (CKD) in children. Hemolytic uremic syndrome is characterized by microangiopathic hemolytic anemia, thrombocytopenia, and acute renal failure that is generally classified into two main types: typical and atypical (aHUS). Hemolytic-uremic syndrome induced by Shigatoxin-producing Escherichia coli (STEC) is the most common type of the disease and ordinarily has a good prognosis, but aHUS is rare that has a poor prognosis with a relapsing course. Extrarenal manifestations may be occured in 25-30\% of cases, including neurological, gastroenterological, cardiac and endocrine involvement (1-4).

Treatment of STEC-HUS is primarily supportive care consisting of volume expansion, antihypertensive therapy, regulation of hematological problems and renal replacement therapy (RRT). Renal replacement therapy is required in 50\%-70\% of cases in the acute phase of typical HUS. General indications for acute $\mathrm{RRT}$ in the management of AKI are applied. Oligoanuria, severe azotemia, electrolyte abnormalities and progressive metabolic acidosis are among the common indications for acute dialysis (5-8). There is no clear benefit for a specific type of RRT. The center experience, technical facilities and patient age are critical factors affecting the choice of RRT for children. End-stage renal disease (ESRD) or death occurs in approximately $12 \%$ of typical HUS cases. Studies evaluating the effects of RRT options on prognosis in children with typical HUS are limited (7-11).

The present study aims (1) to evaluate the clinical and laboratory findings of patients diagnosed with typical HUS, (2) assessment the effects of RRT modalities on prognosis and (3) to determine the utility of inflammation markers in predicting neurological involvement.

\section{MATERIALS and METHODS}

Forty-nine pediatric patients, aged between 0 and 18 years, who had been diagnosed with typical HUS in Dr. Sami Ulus
Maternity and Children's Health and Diseases Training and Research Hospital, Department of Pediatric Nephrology between 2005 and 2020, and who were also followed up for at least 12 months were assessed in this study. The complete triad of HUS is defined as hemolytic anemia characterized by a hemoglobin $(\mathrm{Hb})$ level $<10 \mathrm{~g} / \mathrm{dL}$, detection of schistocytes in peripheral blood smear with a negative Coombs test confirming microangiopathic hemolysis, thrombocytopenia with a platelet count $<150 \times 109 / \mathrm{L}$, and the presence of acute renal failure. Patients with aHUS such as inherited forms of HUS and HUS secondary to organisms other than STEC were excluded $(1,2)$.

Nonspecific indications for RRT in the context of $\mathrm{AKI}$ were applied, the most common being persistent oliguria or anuria, clinical manifestations of uremia, hyperkalemia, severe metabolic acidosis, persistent and symptomatic hyponatremia unresponsive to conservative treatment, whereas these indications are nonspecific and the general consensus in our center is that RRT should be offered early (12-14).

The new Schwartz formula $(K=0.413)$ was used to calculate the estimated glomerular filtration rate (eGFR) (15). Proteinuria was defined when urinary protein creatinine ratio is above 0.2 $\mathrm{mg} / \mathrm{mg}$ or 24-h protein excretion was $>4 \mathrm{mg} / \mathrm{m}^{2} / \mathrm{h}$ in at least two consecutive evaluations (16). Hypertension was defined as a systolic blood pressure and/or diastolic blood pressure $\geq 95$ th percentile, according to age, gender, and height (17).

Neurological involvement was defined as encephalopathy, focal neurological deficit, and/or seizure activity $(5,7)$. The groups with and without neurological involvement were compared concerning inflammatory markers. The neutrophil to lymphocyte ratios and platelet to lymphocyte ratio were calculated using the data obtained from the hemogram analyses. Systemic immune-inflammation index (SII) was calculated from the equation SII = Platelet $\mathrm{x}$ neutrophil count/lymphocyte count.

Dialytic management and therapeutic decisions in our children were individualized based on the patient's age, specific clinical and hemodynamic status. RRT available in our center includes PD, intermittent hemodialysis (IHD), or continuous renal replacement therapies. Temporary vascular access was established (HD catheter insertion into the internal jugular, 
subclavian or femoral vein) or peritoneal access was established by placing a double-cuff tunneled Tenckhoff catheter inserted.

Patients werefollowed up closely for 30 days after beginning RRT. Dialysis was interrupted when there was partial renal function recovery, defined as the restoration of diuresis associated with a progressive fall in serum values for creatinine and urea. At the 3-month follow-up, we categorized all surviving patients as per the Kidney Disease: Improving Global Outcomes (KDIGO) Chronic Kidney Disease (CKD) classification (18).

Patientsmedicalrecords, including such clinicaland demographic characteristics as age, gender, physical examination findings, including blood pressure, and such laboratory findings as routine blood and urine test, complement $\mathrm{C} 3, \mathrm{C} 4$, Coombs test, DIC (disseminated intravascular coagulation), blood and specific stool culture test, lactate dehydrogenase $(\mathrm{LDH})$ level and C-reactive protein (CRP), were retrospectively reviewed. Data on respective RRT therapies, procedure complications, the necessity for mechanical ventilation, and their prognosis were reviewed retrospectively through patient files.

The protocol for this study was approved by the Dr. Sami Ulus Maternity and Child Health and Diseases Training and Research Hospital Ethics Committee (Number: E-21/03-11904.03.2021).

\section{Statistical analyses}

Statistical analysis was performed using IBM SPSS Statistics for Windows v.22.0 (IBM Corp., Armonk, NY, USA). The Kolmogorov-Smirnov test was used to determine the normality of the distribution of the study variables. Parametric variables were shown as mean $\pm S D$, and nonparametric variables were shown as median (range). Categorical variables were presented as numbers and percentages. The student's t-test was used to compare parametric variables and the Mann-Whitney $U$ test was used to compare nonparametric variables. The $x^{2}$ test or Fisher's exact test was used to compare categorical variables. Kaplan-Meier survival analysis was performed and the renal survival probability was compared between the study arms using log-rank test. A value of $p<0.05$ was accepted as being statistically significant.

\section{RESULTS}

The present study included 49 children with typical HUS, and the mean age was $2.99 \pm 1.88$ years. The male-to-female ratio was 1:1.2. At presentation, $43 / 49$ (87.7\%) children had diarrhea, of whom 9/49 (18.3\%) had bloody diarrhea. At admission, 24 (49\%) patients had oliguria, and 20 (40.8\%) patients had anuria. Other main clinical manifestations included edema, vomiting, and dehydration $(87.7 \%, 48.9 \%, 10.2 \%$, respectively). At the presentation time, the mean serum creatinine level was 3.9 $\pm 1.93 \mathrm{mg} / \mathrm{dL}$, and the mean eGFR was $20.37 \pm 19.11 \mathrm{~mL} /$ $\mathrm{min} / 1.73 \mathrm{~m}^{2} . \mathrm{C}_{3}$ complement was low in $12.2 \%$ of the patients, C4 complement was low in 10.2\%. All patients had high LDH levels. Thirty (61.2\%) patients were hypertensive at admission or during hospitalization. Concomitant hematuria and proteinuria were detected in 23 (46.9\%) of the patients (Table I).

Neurological involvement was detected in 15 (30.6\%) patients. The most common presentation was seizures and encephalopathy for neurological involvement. Electroencephalogram and neuroimaging were performed in all these children during the acute illness for diagnosis. Patients with neurological involvement required significantly more mechanical ventilation $(p=0.01)$. The neutrophil/lymphocyte ratio (NLR) was significantly higher in the neurological involvement group [odds ratio $(\mathrm{OR}) 15.42,95 \% \mathrm{Cl}$ (3.39-70.1), $p=0.005]$, whereas white blood cell count (WBC), neutrophil, platelet counts, platelet/lymphocyte ratio (PLR) and SII values were not significantly different between the groups. Lactate dehydrogenase concentration was no significant difference in the groups $(p>0.05)$ (Table II). Of the 15 children with neurological involvement, 14 (93.3\%) achieved a complete neurological recovery.

In total, 43 (87.7\%) patients received RRT. While throughout RRT, $10.2 \%$ of patients required mechanical ventilation. The median time from the first recorded symptom to RRT was six

\begin{tabular}{|c|c|}
\hline Female gender,* $^{*}$ & $27(55.1)$ \\
\hline Patient age, years, ${ }^{\dagger}$ & $2.99 \pm 1.88$ \\
\hline Mechanical ventilation, ${ }^{*}$ & $5(10.2)$ \\
\hline Anuria, $^{*}$ & $20(40.8)$ \\
\hline Baseline hemoglobin $(\mathrm{g} / \mathrm{dl}){ }^{\dagger}$ & $8.02 \pm 1.7$ \\
\hline Baseline platelet count $\left(\times 10^{9} / L\right){ }^{\dagger}$ & $63.81 \pm 39.19$ \\
\hline Baseline white blood count was (x10\%/L), ${ }^{\dagger}$ & $14.56 \pm 7.65$ \\
\hline Baseline lactate dehydrogenase $(\mathrm{U} / \mathrm{L})^{,}{ }^{\dagger}$ & $2322.2 \pm 712.64$ \\
\hline Baseline serum BUN (mg/dl), ${ }^{\dagger}$ & $85.27 \pm 38.76$ \\
\hline Baseline serum creatinine $(\mathrm{mg} / \mathrm{dll}),{ }^{\dagger}$ & $3.9 \pm 1.93$ \\
\hline Baseline eGFR (ml/min/1.73 $\left.\mathrm{m}^{2}\right)^{\dagger}$ & $20.37 \pm 19.11$ \\
\hline Baseline serum sodium (mEq/L), ${ }^{\dagger}$ & $131.14 \pm 4.13$ \\
\hline Baseline serum potassium (mEq/L), ${ }^{\dagger}$ & $4.94 \pm 1.08$ \\
\hline Baseline blood pH, $\uparrow$ & $7.32 \pm 0.05$ \\
\hline $\begin{array}{l}\text { Baseline } \mathrm{HCO}_{3}{ }^{-}{ }^{\dagger} \\
\text { Dialysis indication, } \\
\text { Oligouria-anuria } \\
\text { Electrolyte imbalances } \\
\text { Others }\end{array}$ & $\begin{array}{c}15.76 \pm 3.33 \\
43(87.7) \\
36(83.7) \\
5(11.6) \\
2(4.7)\end{array}$ \\
\hline Time to start of RRT (days), median, (range) & $6(3-11)$ \\
\hline Renal insufficiency, ${ }^{*}$ & $5(10.2)$ \\
\hline Hypertension in survivors, ${ }^{*}$ & $2(4.1)$ \\
\hline Proteinuria in survivors, ${ }^{*}$ & $3(6.1)$ \\
\hline
\end{tabular}

${ }^{*} n(\%),{ }^{+}$mean $\pm S D$ 
Table II: Clinical characteristics and laboratory parameters of patients with and without neurological involvement.

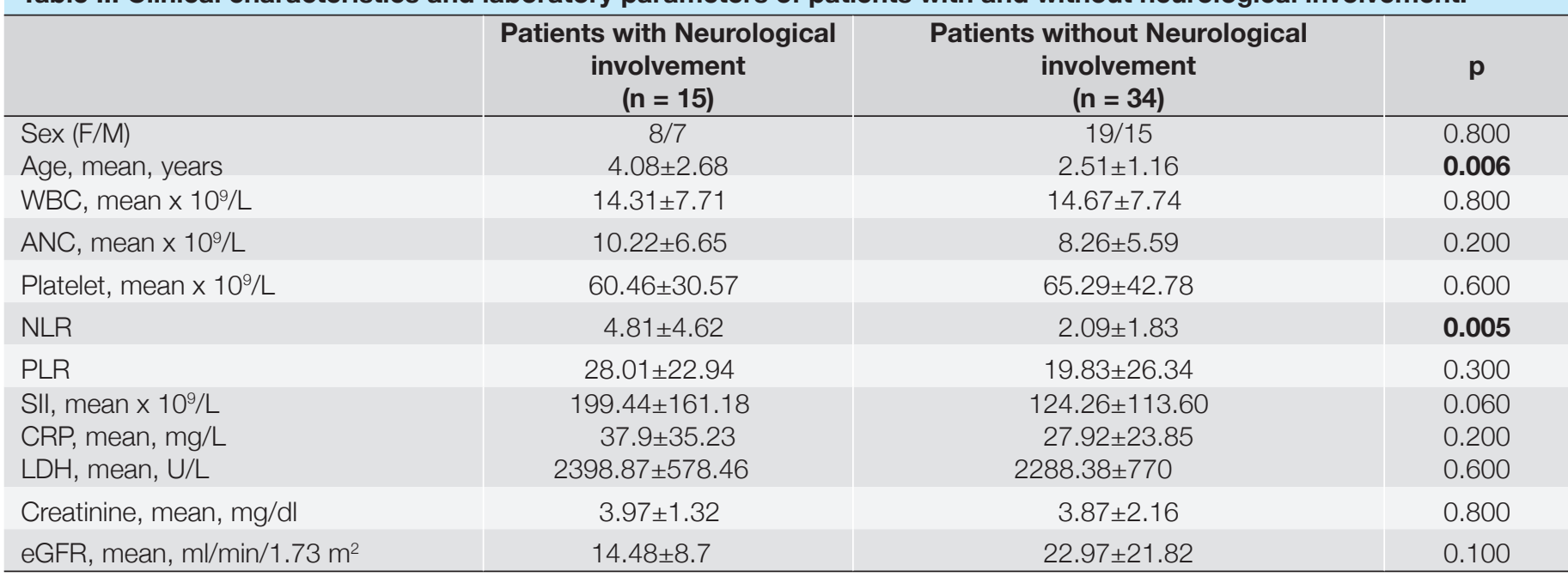

WBC: white blood cell count, ANC: absolute neutrophil count, NLR: neutrophil/lymphocyte ratio, PLR: platelet/lymphocyte ratio, SII: Systemic immune-inflammation index, CRP: C-reactive protein, $\mathbf{D} \boldsymbol{H}$ : lactate dehydrogenase, eGFR: estimated glomerular filtration rate

days (range 3-11). Twenty-six (53.1\%) patients were managed with $\mathrm{PD}$, and 17 (34.6\%) patients were managed with HD. Continuous venovenous hemodialysis (CVVHD) was started at admission in six patients who were septic and hemodynamically unstable and then continued with IHD. The internal jugular vein is the most common vascular access site for extracorporeal dialysis in $76.4 \%$ of the centers, followed by the femoral vein (23.5\%). Peritoneal access was established by placement of a double-cuff tunneled Tenckhoff catheter inserted. The characteristics of the two cohorts were not different, except that children selected for PD were significantly younger than those recruited for IHD $(p=0.01)$. The main indications for dialysis were oliguria and anuria in both groups.

The median number of IHD sessions was seven (range 3-35); the mean session duration was $137.70 \pm 16.37 \mathrm{~min}$. The post/ pre-BUN ratio was 0.58 in the first IHD session. Bicarbonate, potassium, and sodium dialysate concentrations were adjusted according to individual requirements. The fluid extraction requirement was specified as $10-15 \mathrm{ml} / \mathrm{kg} / \mathrm{h}$ per dialysis session, and the weight loss did not exceed $5 \%$ of the patient's body weight. The mean blood flow rate was $5.71 \pm 1.16 \mathrm{ml} / \mathrm{kg} /$ $\mathrm{min}$, and the mean dialysate flow rate was $500 \mathrm{ml} / \mathrm{min}$. Lowmolecular-weight heparin $(\mathrm{LMWH})$ was used for anticoagulation in $59.1 \%$ of IHD sessions. The median duration of PD was four (range 10-25) days. The mean holding volume was $676.92 \pm$ $89.70 \mathrm{ml} / \mathrm{m} 2$. PD solution containing 1.36, 2.27, and $3.86 \%$ glucose was used in $76.92 \%, 26.92 \%$ and $3.84 \%$ of children, respectively.

Although blood volume was monitored during IHD sessions, three patients (17.6\%) had transient hypotensive episodes, and two patients (11.7\%) had transient hypertensive episodes during or within one hour of IHD sessions. In contrast, there were no transient hypertensive or hypotensive episodes with PD. Catheter occlusion (11.7\%) was the most common complication during IHD; resolved with catheter replacement, catheter infection was detected in 5.88\% of the patients. Peritonitis occurred in four patients with PD (15.3\%) and the PD effluent turned sterile in all cases with intraperitoneal antibiotic therapy. Catheter leak and migration were the main mechanical complications in PD, resolved by catheter repositioning and reducing the volume of dialysate per cycle. Mechanical complications occurred with similar frequency in both treatment modalities (PD 11.5\% vs. IHD 11.7\%).

Renal function returned to normal in $24.4 \%$ of the patients after two weeks, in $67.3 \%$ of the patients at the end of the first month. The rate of patients with complete kidney recovery (eGFR> $90 \mathrm{ml} / \mathrm{min} / 1.73 \mathrm{~m}^{2}$ ) was $89.7 \%$ in the third month. Except for patients who developed CKD, the need for dialysis continued for a median of 9 days (range 3-35), and renal failure continued for a median of 22 days (range 7-84). During the follow-up, hypertension was detected in $4.08 \%$ and proteinuria was present in $6.1 \%$ of all patients. Albeit the follow-up of the patients is still carried on in our department, there was one patient (2.04\%) with ESRD, and four patients (8.16\%) were assessed as stage 2 or stage 3 CKD.

In the HD group, the renal function returned to normal in $23.5 \%$ of the patients after two weeks and in $58.8 \%$ of the patients after first month. In the PD group, the renal function returned to normal in $15.3 \%$ of the patients after two weeks and in $65.3 \%$ of the patients after the first month. When two groups were compared, no significant difference was found between normalization of renal function at the end of two weeks and first month ( $p=0.3, p=0.4$, respectively). The mean biochemical indices of renal function were better in patients who received $\mathrm{PD}$ at three months than those who received HD $(p=0.04)$. The choice of RRT modality (PD vs. HD) significantly affected CKD 
Table III: Comparison of clinical and laboratory characteristics of patients received hemodialysis and peritoneal dialysis.

\begin{tabular}{|c|c|c|c|}
\hline & $\begin{array}{c}\text { Peritoneal diyalisis } \\
(n=26)\end{array}$ & $\begin{array}{c}\text { Hemodiyalisis } \\
(n=17)\end{array}$ & p \\
\hline Female gender, ${ }^{\star}$ & $18(69.2)$ & 9 (52.9) & 0.200 \\
\hline Patient age, years, mean \pm SD & $2.45 \pm 1.04$ & $4.05 \pm 2.62$ & 0.008 \\
\hline Mechanical ventilation, ${ }^{*}$ & $1(3.8)$ & $4(23.5)$ & 0.040 \\
\hline Anuria, ${ }^{*}$ & $11(42.3)$ & $9(52.9)$ & 0.300 \\
\hline Time to start of RRT (days), median, (range) & $6.5(4-11)$ & $6(3-11)$ & 0.500 \\
\hline Serum creatinine (mg/dl), median, (range) & $4.13 \pm 2.09$ & $4.44 \pm 1.2$ & 0.500 \\
\hline eGFR (ml/min/1.73 m2), median, (range) & $17.93 \pm 16.29$ & $11.58 \pm 16.29$ & 0.100 \\
\hline Hemoglobin $(g / d l)$, mean \pm SD & $7.5 \pm 1.33$ & $8.35 \pm 2.01$ & 0.100 \\
\hline Platelet count $\left(x 10^{9} / L\right)$, mean $\pm S D$ & $68.8 \pm 46.21$ & $55.82 \pm 30.17$ & 0.300 \\
\hline Lactate dehydrogenase $(\mathrm{U} / \mathrm{L})$, mean $\pm \mathrm{SD}$ & $2350.88 \pm 540.96$ & $2547.06 \pm 775.11$ & 0.300 \\
\hline Renal insufficiency, ${ }^{\star}$ & $1(3.8)$ & $4(23.5)$ & 0.040 \\
\hline Hypertension, ${ }^{*}$ & $1(3.8)$ & $1(5.8)$ & 0.700 \\
\hline Proteinuria, ${ }^{*}$ & $1(3.8)$ & $2(11.7)$ & 0.300 \\
\hline
\end{tabular}

RRT: renal replacement threapy, eGFR: estimated glomerular filtration rate, ${ }^{*} n(\%)$

risk at the end of the three months (odds ratio (OR) 7.69, 95\% $\mathrm{Cl}(0.77-76.07), \mathrm{p}=0.04)$ (Figure 1). The need for mechanical ventilation was significantly higher in the CKD group $(p=0.04)$ (Table III).

\section{DISCUSSION}

A subset of typical HUS patients requires initiation of RRT despite aggressive medical intervention. Based on data from observational studies and comparative clinical studies, there is no consensus on the best dialysis technique and optimal dialysis dose in HUS (8-10). In this study, we analyzed the efficacy and safety of PD and HD were compared in managing typical pediatric HUS. The CKD rate was significantly higher in the HD group than in the PD group $(p=0.04)$. In addition, we determined the utility of inflammation markers in predicting neurological involvement, which is one of the most severe complications of typical HUS. The neutrophil/lymphocyte ratio (NLR) was significantly higher in the neurological involvement group [odds ratio (OR) 15.42, 95\% Cl (3.39-70.1), $p=0.005$ ].

The present study evaluated the clinical and laboratory findings of patients diagnosed with typical HUS. In the literature, the male-to-female ratio was 1.7-1.4, and the median age was 17 months (range 10-108) of typical HUS. The most common complaints of the cases were diarrhea (30-60\%) and bloody diarrhea (25-40\%). Anuria development rate was 40-80\% $(19,20)$. Hypertension was found in $40-50 \%$ and proteinuria in $50 \%$ of the cases. Proteinuria persisted for a long time in $4-10 \%$ of cases (19-21). Zhao et al. (22) showed a $20 \%$ decrease in $\mathrm{C}_{3}$. Our study included 49 children with typical HUS, and the mean age was $2.99 \pm 1.88$ years. The maleto-female ratio was 1:1.2. At presentation, $43 / 49$ (87.7\%) patients had diarrhea, of whom 9/49 (18.3\%) had bloody diarrhea. At the time of admission, 20 (40.8\%) patients had anuria. $\mathrm{C}_{3}$ complement was low in $12.2 \%$ of the patients. Thirty (61.2\%) patients were hypertensive at admission or during hospitalization. Concomitant hematuria and proteinuria were detected in 23 (46.9\%) of the patients.

Typical HUS is not specific for indications for initiating RRT in children, management of oliguria, metabolic acidosis, and electrolyteabnormalities. However, thereisacommonconsensus that RRT should correct any biochemical abnormalities while maintaining adequate fluid and electrolyte balance to ensure organ function and functional recovery. Dialytic management of these patients is challenging because of multiple organ dysfunction and associated hemodynamic instability. The most appropriate RRT choice for children with typical HUS is based on the patient's age, characteristics, dialytic modality performance, and institutional resources and local practice $(7,8,23,24)$. In this study, RRT management and treatment decisions in our children were individualized according to the patient's age, specific clinical and hemodynamic status. In this study, 43 (87.7\%) patients received RRT. Twenty-six (53.1\%) patients were managed with $\mathrm{PD}$, and 17 (34.6\%) patients were managed with HD. Continuous venovenous hemodialysis was started at admission in six patients who were septic and hemodynamically unstable and then continued with IHD. The most common indication for dialysis was oliguria-anuria (88.3\%) and electrolyte disturbances (11.6\%).

In typical HUS, all tissues and organs may be affected due to thrombotic microangiopathy, and signs of neurological involvement can be seen in $25-30 \%$ of cases. Lethargy, irritability and seizure are the most common findings. In studies conducted so far, markers to predict neurological involvement in patients have not been determined; some clinical scorings have been used. Rapid treatment of neurological involvement in typical HUS provides recovery without sequelae $(25,26)$. In 
our study, neurological involvement was detected in 15 (30.6\%) patients. Patients with neurological involvement required significantly more mechanical ventilation ( $p=0.01)$. The neutrophil/lymphocyte ratio (NLR) was significantly higher in the neurological involvement group [odds ratio (OR) 15.42, 95\% Cl (3.39-70.1), $\mathrm{p}=0.005]$, whereas WBC, neutrophil, platelet counts, PLR and SIl values were not significantly different between the groups. Of the 15 children with neurological involvement, 14 (93.3\%) achieved a complete neurological recovery.

PD is frequently used in treating typical pediatric HUS and remains the method of choice in infants and young children for whom vascular access is a limiting factor. In addition to avoiding central venous puncture and anticoagulation, technical simplicity, relatively low cost, and low risk of treatment-related fluid-electrolyte imbalances in hemodynamically unstable patients are considered significant advantages of PD. On the other hand, the availability of significant technological advances in $\mathrm{HD}$ and CVVHD in children is decreasing the use of PD for children who need RRT $(7,8,19,20)$. When HD and PD groups were compared, no significant difference was found between normalization of renal function at the end of two weeks and the first month ( $p=0.3, p=0.4$, respectively). The mean biochemical indices of renal function were better in patients who received $P D$ at three months than those who received $\mathrm{HD}(\mathrm{p}=0.04)$. The choice of RRT modality (PD vs. HD) significantly affected CKD risk at the end of the three months (odds ratio (OR) 7.69, 95\% $\mathrm{Cl}(0.77-76.07), \mathrm{p}=0.04)$. This finding may be because, in more severe and hemodynamically unstable patients, continuous RRT was started and then continued with hemodialysis.

In studies comparing $\mathrm{HD}$ and PD, transient hypotensive and hypertensive episodes were higher and mechanical complications were similar who received HD (12,13). The findings showed that three patients (17.6\%) had transient hypotensive episodes, and two patients (11.7\%) had transient hypertensive episodes during or within an hour of IHD sessions. In contrast, there were no transient hypertensive or hypotensive episodes with PD. Mechanical complications occurred with similar frequency in both treatment modalities (PD 11.5\% vs. IHD 11.7\%).

Our study had some limitations. The present study reflected single-center data, the number of patients was limited, and it was designed as a retrospective study. However, our study will contribute to the literature, given that this is one of the few studies evaluating the effects of RRT modalities on renal survival and determining the utility of inflammation markers in predicting neurological involvement.

In conclusion, this study represents a valuable contribution to the modest existing evidence supporting the use of PD in children with typical HUS who need RRT. We evaluated the mean biochemical indices of renal function that were better in patients who received $P D$ at three months than those who received HD. Hence, we concluded that PD might be as effective and safer as HD concerning kidney recovery. The use of clinical features and inflammatory markers to predict neurological involvement in typical HUS cases can be developed in further studies.

\section{REFERENCES}

1. Viteri B, Saland JM. Hemolytic Uremic Syndrome. Pediatr Rev 2020;41:213-5.

2. Besbas N, Karpman D, Landau D, Loirat C, Proesmans W, Remuzzi G, et al. European Paediatric Research Group for HUS: A classification of hemolytic uremic syndrome and thrombotic thrombocytopenic purpura and related disorders. Kidney Int 2006;70:423-31.

3. Fakhouri F, Zuber J, Fre 'meaux-Bacchi V, Loirat C. Haemolytic uraemic syndrome. Lancet 2017;390:681-96.

4. Salvadori M, Bertoni E. Update on hemolytic uremic syndrome: diagnostic and therapeutic recommendations. World $\mathrm{J}$ Nephrol 2013;2:56-76.

5. Walsh PR, Johnson S. Treatment and management of children with haemolytic uraemic syndrome. Arch Dis Child 2018;103:285-91.

6. Talarico V, Aloe M, Monzani A, Miniero R, Bona G. Hemolytic uremic syndrome in children. Minerva Pediatr 2016;68:441-55.

7. Grisaru S. Management of hemolytic-uremic syndrome in children. Int J Nephrol Renovasc Dis 2014;7:231-9.

8. Bitzan M. Treatment options for HUS secondary to Escherichia coli O157:H7. Kidney Int Suppl 2009;(112):S62-6.

9. Tarr PI, Gordon CA, Chandler WL. Shiga-toxin-producing Escherichia coli and haemolytic uraemic syndrome. Lancet 2005;365:1073-86.

10. Trachtman H, Cnaan A, Christen E, Gibbs K, Zhao S, Acheson DWK, et al. Investigators of the HUS-SYNSORB PK Multicenter Clinical Trial. Effect of an oral Shiga toxin-binding agent on diarrheaassociated hemolytic uremic syndrome in children: a randomized controlled trial. JAMA 2003;290:1337-44.

11. Rosales A, Hofer J, Zimmerhackl LB, Jungraithmayr TC, Riedl M, Giner T, et al. Need for long-term follow-up in enterohemorrhagic Escherichia coli-associated hemolytic uremic syndrome due to late-emerging sequelae. Clin Infect Dis 2012;54:1413-21.

12. Basu B, Mahapatra TK, Roy B, Schaefer F. Efficacy and outcomes of continuous peritoneal dialysis versus daily intermittent hemodialysis in pediatric acute kidney injury. Pediatr Nephrol 2016;31:1681-9.

13. Bunchman TE. Treatment of acute kidney injury in children: from conservative management to renal replacement therapy. Nat Clin Pract Nephrol 2008;4:510-4.

14. Palevsky PM, Liu KD, Brophy PD, Chawla LS, Parikh CR, Thakar CV, et al. KDOQI US commentary on the 2012 KDIGO clinical practice guideline for acute kidney injury. Am J Kidney Dis 2013;61:649-72.

15. Schwartz GJ, Muñoz A, Schneider MF, Mak RH, Kaskel F, Warady BA, et al. New equations to estimate GFR in children with CKD. J Am Soc Nephrol 2009;20:629-37.

16. Ariceta G. Clinical practice: proteinuria. Eur J Pediatr 2011;170:1520.

17. Lurbe E, Agabiti-Rosei E, Cruickshank JK, Dominiczak A, Erdine S, Hirth A, et al. 2016 European Society of Hypertension guidelines 
for the management of high blood pressure in children and adolescents. J Hypertens 2016;34:1887-920.

18. Levey AS, Coresh J, Balk E, Kausz AT, Levin A, Steffes MW, et al. National Kidney Foundation practice guidelines for chronic kidney disease: evaluation, classification, and stratification. Ann Intern Med 2003;139:137-47.

19. Micheletti M V, LavorattiG, Materassi M, Pela I. Hemolytic Uremic Syndrome: Epidemiological and Clinical Features of a Pediatric Population in Tuscany. Kidney Blood Press Res 2010;33:399-404.

20. Balgradean M, Croitoru A, Leibovitz E. An outbreak of hemolytic uremic syndrome in southern Romania during 2015-2016: Epidemiologic, clinical, laboratory, microbiologic, therapeutic and outcome characteristics. Pediatr Neonatol 2019;60:87-94.

21. Jenssen GR, Vold L, Hovland E, Bangstad HJ, Nyard K, Bjerre A. Clinical features, therapeutic interventions and long-term aspects of hemolytic-uremic syndrome in Norwegian children: a nationwide retrospective study from 1999-2008. BMC Infect Dis 2016;16:285.
22. Zhao SA, Ning BT, Mao JH. Clinical characteristics of children with hemolytic uremic syndrome in Hangzhou, China. World J Pediatr 2017;13:183-5.

23. Scheiring J, Andreoli SP, ZimmerhackI LB. Treatment and outcome of Shiga-toxin associated hemolytic uremic syndrome (HUS). Pediatr Nephrol 2008;23:1749-60.

24. McKee RS, Schnadower D, Tarr PI, Xie J, Finkelstein Y, Desai N, et al. Predicting hemolytic uremic syndrome and renal replacement therapy in Shiga toxin-producing Escherichia coli-infected children. Clin Infect Dis 2020;70:1643-51.

25. Costigan C, Raftery T, Carroll AG, Wildes D, Reynolds C, Cunney $R$, et al. Neurological involvement in children with hemolytic uremic syndrome. Eur J Pediatr 2022;181:501-12.

26. Nathanson S, Kwon T, Elmaleh M, Charbit M, Launay EA, Harambat $\mathrm{J}$, et al. Acute neurological involvement in diarrhea associated hemolytic uremic syndrome. Clin J Am Soc Nephrol 2010;5:121828 